International

Medical Society

http://imedicalsociety.org

\title{
Violence Against Women and its Representations: an Integrative Review
}

Maria Cidney da Silva Soares ${ }^{1}$, Renata Clemente dos Santos ${ }^{2}$, Jaquelline Pereira Moura ${ }^{3}$, Therezza Virgínia Vital Freire ${ }^{3}$, Heloiza Talita Adriano da Silva², Maria Djair Dias ${ }^{4}$

\section{Abstract}

Background: To review the scientific literature on violence against women.

Method: Integrative review carried out in the Virtual Health Library, in June and July 2015. These inclusion criteria were considered: full text and freely available; female public; studies carried out in Brazil; in Portuguese; with 2011-2014 time frame.

Results: The sample was composed of 15 publications, all found in the LILACS (100\%) database, of which 9 (60\%) had publications in $A_{2}$ magazines, $4(26.6 \%)$ in $B_{1}$ magazines and $2(13.4 \%)$ in Qualis $\mathrm{B}_{2}$ magazines. Most of the publications was Quantitative 8 approach (53.3\%), showing different thematic perspectives and 7 (46.6\%) were qualitative, applying violence in the perception of women and professionals who offer them assistance.

Conclusions: It is essential to find coping strategies for violence, as well as the effective detection in primary health care.

\section{Introduction}

The naturalization of violence against women, mainly due to the sociocultural construction and guided by the relations linked to gender, has been identified as one of the most troubling public health problems in recent decades.

Despite numerous achievements by women in struggles in feminist movements, gender violence persists in society over the years, mainly because it is a phenomenon linked to the issues in depth
1 Teacher. Medical Sciences College. Campina Grande. Paraíba, Brazil. PhD student in Nursing. Nursing Department. Federal University of Paraíba, UFPB. João Pessoa, Paraíba, Brazil.

2 Master's Degree in Nursing. Nursing Department. Federal University of Rio Grande do Norte, UFRN. Natal, Rio Grande do Norte, Brazil.

3 Nurse. Member of the Group of Studies and Research in Nursing of the Medical Sciences College. Campina Grande, Paraíba, Brazil.

5 Teacher, Doctor in Nursing. Nursing Department. Federal University of Paraíba, UFPB. João Pessoa, Paraíba, Brazil.

Contact information:

Renata Clemente dos Santos.

” renata.clemente@hotmail.com

Keywords

Violence; Woman; Gender. 
gender inequalities and patriarchal culture that still exists today.

Recent studies indicate that in the period of 20012011, the Mortality Information System recorded a total of 44,231 deaths of women for aggression, showing that the numbers of all women affected by death aggression little changed after the term of the Maria da Penha Law, which was enacted on August 7th, 2006, demonstrating that without concerted effort to change the culture of naturalization of this event, the problem of violence against women will be passed on from generation to generation. [1]

Although the data show little difference between these rates, it is known that after the Maria da Penha Law the number of women seeking protection in law is notorious, and consequently they left the invisibility which characterizes the violence against women cycle. The encouragement of these women to denounce the aggressors occurs due to the greater amount of information about their rights and the knowledge of the law, which has been widely publicized. [2]

The visibility and recognition that the violence problem has acquired by society is the result of a process that extends to today on mobilizing and organizing movements, that don't mute for the historic violence perpetuated against women.

Considering the relevance of the proposed thematic, we posed these questions: What do the results of the studies already published indicate on violence against women?

In this view, the present study aims to analyze the scientific literature on violence against women and the results presented in publications as well as to characterize them according to the type of study, periodic and region of Brazil where they were performed.

\section{Methods}

This is an integrative review, with qualitative approach to periods from January 1st, 2011 to Decem- ber 31st, 2014, related to violence against women and gender implications.

This type of method aims to deepen understand the theme, gathering and organizing the research on the subject in a systematic and orderly manner. [3]

For the preparation of this integrative review, there were covered six construction stages: defining the research question, designing the inclusion and exclusion criteria, database definition, choosing of descriptors used in the research, data analysis, presenting results and finally performing the synthesis of knowledge. [3]

Search in pairs was carried out in the Virtual Library of Health (BVS), in independent manner, by this guiding question: What do the results of the studies already published indicate on violence against women? From the descriptors base in Health Sciences (DeCS), the following descriptors were defined: Gender, Women and Violence, then these were applied separately to the BVS. For the "Woman" descriptor, there were identified in said library 59,669 journals. For the "Violence" descriptor, there were 43,727 journals and for the "Gender" descriptor, there were 107,354 (Figure 1).

Figure 1: Initial search with individualized descriptors in the Virtual Health Library. Campina Grande, 2015.

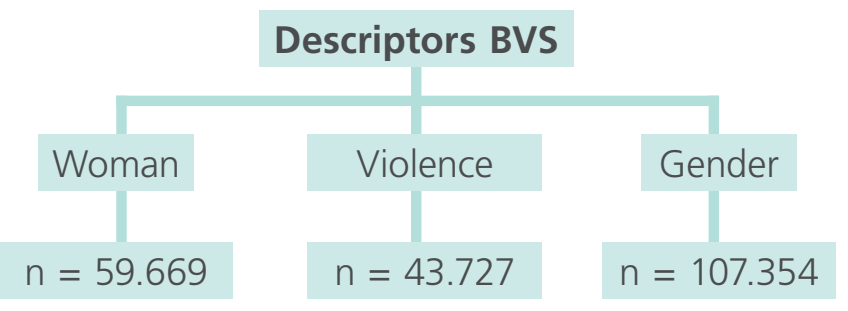

Then, the Boolean operators "Woman" and "Violence" and "Gender" were applied, emerging from an initial population of 817 journals. From the inclusion criteria: journals indexed in the BVS, full text and available for free, female audience, in the region of Brazil, in Portuguese language, with time frame between 2011 and 2014. A sample of 
17 journals resulted in the end of the search. The identification of the articles according to the author, year, volume, title, objectives, methodology, results and conclusion (Figure 2).

Figure 2: Flowchart. Boolean operators and filters in the Virtual Health Library. Campina Grande, Brazil, 2015.

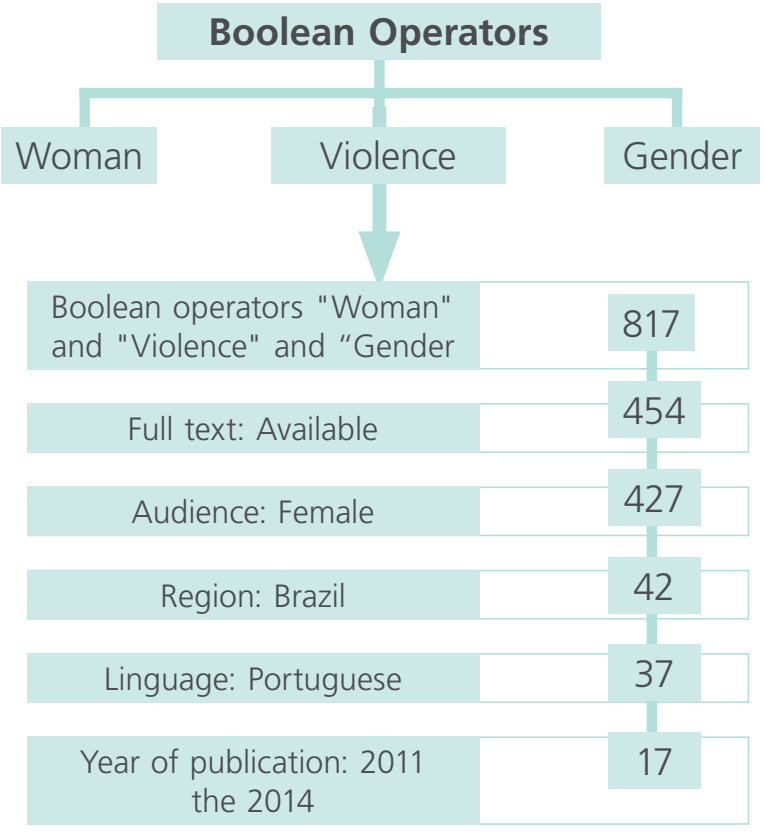

Of the 17 selected journals, two publications were excluded, one by not showing the name of the journal, year of publication and volume, and the other because it was a summary, resulting in a final sample of 15 journals, all indexed in LILACS database.
Aimed at reducing biases of research and giving greater reliability, we used an instrument to assess the methodological rigor of the journals pointing their levels of evidence, which can range from I to VI. [3]

In the next phase, a reading of selected articles was performed. And the data were collected from the preparation of a summary table established by the researchers, which ensured that the review was developed with scientific rigor, guided by the following: article title, year, location, approach, periodic, Qualis of the publications and level of evidence.

After selecting and reading the articles, there were considered all aspects and meanings involved in each of them and identified the main ideas of the content related to the topic of study in the pursuit of themes which characterized the present analysis. And at the end of this exercise, the following categories emerged: Quantitative approach, Qualitative approach: The victim's perception of violence and Qualitative approach: professionals' perception.

\section{Results}

From the research carried out in the BVS, the sample of this review totaled 15 items (Table 1), all found in the LILACS database.

The analysis pointed out that there was no significant prevalence regarding the methodological approach employed in the research. Of the 15 arti-

Table 1. Table 1 - Characterization of the articles found. Campina Grande/PB, Brazil, $2015 .$.

\begin{tabular}{|l|l|l|l|l|l|l|l|}
$\mathbf{N}$ & \multicolumn{1}{c|}{ Title } & Year & Location & Approach & Journal & Qualis & $\begin{array}{l}\text { Level of } \\
\text { Evidence }\end{array}$ \\
\hline 1 & $\begin{array}{l}\text { Social resources to support women in situation } \\
\text { of violence in Ribeirão Preto, SP, in the } \\
\text { perspective of key informants }\end{array}$ & 2011 & São Paulo & Qualitative & Interface & B2 & IV \\
\hline 2 & $\begin{array}{l}\text { Domestic violence against women and } \\
\text { professional intervention in primary healthcare: } \\
\text { an ethnographic study in Matinhos, Paraná } \\
\text { State, Brazil. }\end{array}$ & 2013 & Paraná & Qualitative & $\begin{array}{l}\text { Cadernos } \\
\text { de Saúde } \\
\text { Pública }\end{array}$ & A2 & IV \\
\hline 3 & $\begin{array}{l}\text { Typical actions from women reporting violence: } \\
\text { contributions to nursing }\end{array}$ & 2011 & $\begin{array}{l}\text { Rio Grande } \\
\text { do Sul }\end{array}$ & Qualitative & $\begin{array}{l}\text { UERJ Nursing B1 } \\
\text { Journal }\end{array}$ & IV \\
\hline
\end{tabular}




\begin{tabular}{|c|c|c|c|c|c|c|c|}
\hline N. & Title & Year & Location & Approach & Journal & Qualis & $\begin{array}{l}\text { Level of } \\
\text { Evidence }\end{array}$ \\
\hline 4 & $\begin{array}{l}\text { Combating violence against women: service } \\
\text { network personnel's Perceptions }\end{array}$ & 2012 & Bahia & Qualitative & $\begin{array}{l}\text { UERJ Nursing } \\
\text { Journal }\end{array}$ & B1 & IV \\
\hline 5 & $\begin{array}{l}\text { Impact of Maria da Penha Law on female } \\
\text { mortality due to aggression in Brazil, 2001-2011 }\end{array}$ & 2013 & Brasilia & Quantitative & $\begin{array}{l}\text { Epidemiol. } \\
\text { Serv. Saúde }\end{array}$ & B2 & V \\
\hline 6 & $\begin{array}{l}\text { Sexual violence: a descriptive study of rape } \\
\text { victims and care in a university referral center in } \\
\text { São Paulo State, Brazil }\end{array}$ & 2013 & São Paulo & Quantitative & $\begin{array}{l}\text { Cadernos } \\
\text { de Saúde } \\
\text { Pública }\end{array}$ & $A 2$ & IV \\
\hline 7 & $\begin{array}{l}\text { Characteristics of women victims of sexual } \\
\text { violence and their compliance with outpatient } \\
\text { follow-up: time trends at a referral center in } \\
\text { Campinas, São Paulo State, Brazil }\end{array}$ & 2011 & São Paulo & Quantitative & $\begin{array}{l}\text { Cadernos } \\
\text { de Saúde } \\
\text { Pública }\end{array}$ & A2 & IV \\
\hline 8 & $\begin{array}{l}\text { Spatial analysis of domestic violence against } \\
\text { women from } 2002 \text { to } 2005 \text { in João Pessoa, } \\
\text { Paraíba State, Brazil }\end{array}$ & 2012 & Paraíba & Quantitative & $\begin{array}{l}\text { Cadernos } \\
\text { de Saúde } \\
\text { Pública }\end{array}$ & A2 & IV \\
\hline 9 & $\begin{array}{l}\text { Critical trajectories of female victims of gender } \\
\text { violence: discourse analysis of women and staff } \\
\text { professionals in Porto Alegre, Rio Grande do Sul } \\
\text { State, Brazil }\end{array}$ & 2011 & $\begin{array}{l}\text { Rio Grande } \\
\text { do Sul }\end{array}$ & Qualitative & $\begin{array}{l}\text { Cadernos } \\
\text { de Saúde } \\
\text { Pública }\end{array}$ & A2 & IV \\
\hline 10 & $\begin{array}{l}\text { Violence against women in the perspective of } \\
\text { community health agents. }\end{array}$ & 2013 & $\begin{array}{l}\text { Rio Grande } \\
\text { do Sul }\end{array}$ & Qualitative & $\begin{array}{l}\text { Revista } \\
\text { Gaúcha de } \\
\text { Enfermagem }\end{array}$ & B1 & IV \\
\hline 11 & $\begin{array}{l}\text { Social medical themes and the health } \\
\text { intervention: violence against women in the } \\
\text { professional's discourse }\end{array}$ & 2011 & São Paulo & Qualitative & $\begin{array}{l}\text { Ciência e } \\
\text { Saúde }\end{array}$ & B1 & IV \\
\hline 12 & $\begin{array}{l}\text { External causes of maternal mortality: proposal } \\
\text { for classification }\end{array}$ & 2013 & Pernambuco & Quantitative & $\begin{array}{l}\text { Revista } \\
\text { de Saúde } \\
\text { Pública }\end{array}$ & A2 & V \\
\hline 13 & Femicides: female homicide in Brazil & 2011 & $\begin{array}{l}\text { Rio Grande } \\
\text { do Sul }\end{array}$ & Quantitative & $\begin{array}{l}\text { Revista } \\
\text { de Saúde } \\
\text { Pública }\end{array}$ & A2 & V \\
\hline 14 & $\begin{array}{l}\text { Factors associated with intimate partner } \\
\text { physical violence among health service users }\end{array}$ & 2011 & São Paulo & Quantitative & $\begin{array}{l}\text { Revista } \\
\text { de Saúde } \\
\text { Pública }\end{array}$ & A2 & IV \\
\hline 15 & $\begin{array}{l}\text { Violence among female users of healthcare } \\
\text { units: prevalence, perspective and conduct of } \\
\text { managers and professionals }\end{array}$ & & São Paulo & Quantitative & $\begin{array}{l}\text { Revista } \\
\text { de Saúde } \\
\text { Pública }\end{array}$ & A2 & IV \\
\hline
\end{tabular}

cles, 8 (53.3\%) had a quantitative approach; while $6(40 \%)$ of them were qualitative and only one was of quanti-qualitative type.

The vast majority of research was carried out in the region of São Paulo (06; 40\%) and Rio Grande do Sul (03; 20\%). The studies were published mainly in Caderno de Saúde Pública (05; 33.3\%) and in the
Revista de Saúde Pública (04; 26.6\%). In assessing the magazine specificity, those for the content related to Public Health amounted to a total of 60\% (09 articles) compared to other types of periodicals, followed by publications related to Nursing (03; 20\%).

By analyzing the Qualis-Nursing of the Magazines, 09 articles were publications in $A_{2}(60 \%)$ ma- 
gazines, followed by publications in Qualis $\mathrm{B}_{1}(04$; $26,6 \%)$ and publications in Qualis $B_{2}(02 ; 13,4 \%)$. Most of these articles was published in 2011 (07; $46.6 \%)$, followed by those published in 2013 (05; $33.3 \%)$.

Regarding the level of evidence, the sample showed no studies classified in I, II, II and VI levels of evidence, pointing to more publications with IV evidence level (12; 80\%), being studies with nonexperimental design with correlational and descriptive qualitative research or case studies; followed by $\checkmark$ evidence level $(03 ; 20 \%)$, which refers to evidence from studies with case or experiences reports.

Among the articles of the sample that pointed to qualitative analysis, it was noted that a higher percentage sought understanding and addressing violence on the perspective of professionals caring for women victims of violence $(7,78 \%)$ while the perception of the women was shown in a much lower percentage $(2,22 \%)$.

\section{Discussions}

This section provides a discussion on the quantitative approach of the journals and the qualitative approach on the perspective of women and of the professionals who offer assistance to the victim of violence.

\section{Quantitative Approach}

The quantitative approach of the sample points varied visions of the subject of violence. When it comes to sexual violence, two studies were conducted at the State University of Campinas - SP. One was conducted from 2000 to 2006 and the other from 2006 to 2010, but by different authors. Statistical data are similar; most of the victims were white women, young, single and sought treatment in less than 24 hours of the event, held Accident Report, were raped in public places, in the night hours (from $6 \mathrm{pm}$ to $6 \mathrm{am})$, with a predominance of vaginal intercourse, in most of them presented good adhesion to the monitoring of follow-up in the sector. $[2,4]$

Performing a comparison between the two results, it is noticeable that there was an increase in the number of women victims of sexual violence in the city studied as the indentations made in the sample; in the period from 2000 to 2006 (period of 7 years) 642 women were served, while from 2006 to 2010 (period of 5 years), there were 762 women. $[2,4]$

Although research has been carried out in the same service, making use of records / record of service data, it was not possible to cross-comparison the two studies for all the victims' profile data. This inability to compare the studies developed in the same service occurred mainly by the absence of information in those files, limiting the availability of important information.

The study carried out through literature review [5] emphasizes the importance of valuing the characterization of the victims of violence, as well as the characterization of violence and the context in which these occurrences resulted; such data allow progress or not, by applicability of public policy, and guide more effective service strategies.

One study conducted in the city of Recife-PE showed 399 deaths of women of childbearing age from 2004 to 2006. From this total deaths, 196 were due to homicide, for a total of $57 \%$ of the sample. It should be noted that 18 deaths by external causes occurred during pregnancy, having occurred yet at the beginning of pregnancy, or early puerperium. These 18 women were mostly black, young people with less than eight years of study, single and their family members were unaware of the existence of pregnancy $(72.2 \%$ were victims of murder). [6]

Regarding the spatial approach to violence against women, one of the articles shows that from 2002 to $2005,2,836$ incidents were recorded occurrences in the police station for women of the city of João Pessoa, and $36 \%$ of the city's neighborhoods had a low incidence of violence in the survey period. Some 
neighborhoods presented a risk between 1.5 to 2 times greater than that of the city of João Pessoa. The study still pointed to a mapping and the risk of domestic violence statistics by neighborhood for each year, demonstrating that violence occurred in all regions of the territorial municipality, demonstrating that the violence against women affects all interchangeably, i.e., affecting all social segments, independently of the social condition and the neighborhood where people live. [7]

A survey conducted with 504 women, of these, $34.5 \%$ suffered at least one episode of intimate partner violence in life. Most were white, Catholic, with less than 8 years of schooling. Separated, divorced and women with lower education levels were more affected by VPI, whereas age, color, religion, and social class were not related to the occurrence of violence. [8]

The chances of suffering violence were greater to those who were householders (96\%), who witnessed violence against the mother (92\%) and his partner witnessed violence against mother (96\%). The marital situation, schooling and family identity were predictors of violence, mainly by gender conflicts. Although it is a prevalence study, its data are not taken into consideration compared to the general population, given the sample size. [8]

A study carried out with 2,379 women in the municipalities of São Paulo State showed that $84.2 \%$ of respondents were between 18 and 49 years old, $66.4 \%$ were married, $49.6 \%$ were working, $53.5 \%$ had at most 8 years of schooling, $42.4 \%$ were white. [9]

Among the respondents, $76.5 \%$ suffered some kind of violence. $56.4 \%$ suffered some intimate partner violence, and if we consider any intimate partner violence in the last 12 months, that number was also high (32.2\% of respondents), $12.4 \%$ had at least one episode of sexual violence in life. 9

One of the sample journals applied quantitative approach to finding feminicide data (death of women) and it was noticed that in the 2003-2007 period, there were approximately 20,000 female deaths by aggression in Brazil, affecting mainly young women (20 to 30 years old), single (61.4\%) and women with low education level (24.5\% with 4 to 7 years of study; it is also noteworthy that $39.2 \%$ did not have such information), 50.7\% were black women and $41.9 \%$ were white, and one third of the deaths occurred in the victims' homes (strengthening the cause of homicides due to gender conflicts, i.e., by femicide). [10]

A study of significant relevance conducted by The Lancet also found that higher women's education level is strongly associated with reduced risk of experiencing intimate partner violence in the regions where there is a "naturalization" of gender violence. In this approach, the authors infer that factors linked to culture guided by gender helps to estimate the prevalence of violence against women in this population, further suggesting that this type of violence is substantially reduced with measures to eliminate gender bias.[11]

An investigation was conducted to observe the connection between female murder and precarious living conditions, which pointed paradoxical or inverse connection, in contrast so to studies that make this poverty and femicide ratio [10]. The study drew still important comparisons between variables of living conditions, education, marital status, religion, among others, that made it possible to infer the connection between violence, feminicide and these variables.

\section{Qualitative Approach: Victim's Perception}

With regard to the perception of women victims of violence, the sample articles showed that in the majority of the cases, violence arises from the nearest people, whether family, friends or colleagues. And that, while family members guarantee support and protection to victims, they also advise the permanence in the relationship. $[12,13]$

In parallel to this reality, one of the studies showed that battered women know their rights and know 
the Police Station for Women. However, they criticize the way officials listened to their testimony, with no interest to the details of their histories, focusing only on filling the occurrence report, diverting attention to facts, that somehow could make a difference at the time of the complaint. Another point that the battered women reported is that they believed that when making the police report, all the aggression problems would be solved. They still show the failure of protective measures against the offenders, leaving it explicit that when they returned to their homes, mistreatment continued or even was accentuate. [13]

Regarding the feelings of women victims of violence, one of the periodic [13] shows that fear, shame, guilt, family pressures, lack of guidance and situations of financial need still hinder the process of denouncing the violence. Their expectations are commonly associated with motivation to stop the violence through denounces, usually associated with fatigue of experiencing the same situation, in addition to the outrage because the author of aggression is a relative or known person, and for fear of death. They also express hope and expectations of resumed their life plans and finally have peace. [12]

\section{Qualitative Approach: Professionals" Perception}

Surveys were applied in the periodic of the sample, with professionals from various social institutions, since women's police station, military police, to the professional outpatient health, and also of primary care. They present an audience with experience and awareness on the issue, in addition to understanding coherently its missions in each government body, as well as the policy in force. $[13,16]$ In contrast, one of the journals pointed to professionals who are unaware of the services that can offer support to women victims of violence, as well as its tasks within the service network. [17] And in another article, some of the professionals pointed to the lack of their responsibilities in primary care. [16]
Although they understand well their duties, professionals report various limitations in the application of Maria da Penha Law, such as the detection of violence and domicile invasion, lack of reporting tools, intersectoral communication difficulties, excessive labor demand and lack of financial resources. [13, 17] Another evident limitation, that deserves to be highlighted, is that many of them feel unable to deal with violence against women by lack of training and coping strategies of the relevant issue. $[13,14]$

The houses to support women victims of violence are shelters that receive them after the outbreak of violence, when they are in situation of threats of assault and/or at risk of homicide. One of the journals [14] pointed to structural limitation on victim care system, as their municipality does not offer the house to support victims of violence. In contrast, authors of another article [13] show a flow of assistance to abused women, where the shelter is part of the municipal service.

There are still very strong moral impressions that are linked to the theme of violence against women, and these views are sometimes formed by professionals, since they tend to say that the raped woman is responsible for the aggression she experienced, being it a fruit of her personal choices, as evidenced in one of the journals of the sample. [16] It is understood that the issue of violence against women is not limited to only biological assistance. Thus, some studies $[13,15,17]$ show that the performance of the health team in the family health strategy is limited to healing interventions. This reality points us to the need for reinforcements in the care network for victims of violence against women, as well as the development of a comprehensive look at this SUS users, understanding that she will present multiple needs that will pervade the experienced physical violence.

Two journals allocated their research to health professionals in primary care. Both of them highlighted the importance of the Community Health Agent role 
as a strategic professional in the detection of violence against women, since he/she has a higher bond of trust and communication with the community. $[15,18]$ One of the articles pointed to the difficulty in detecting cases of violence and pointed to the host at the healthcare facility unit as an effective strategy to achieve the detection of violence, though it does not perform effective monitoring to women, treating them only in the biological area. [15]

In interviews with professionals of the Family Health Program (PSF) in the city of Campina Grande-PB, it was evident the poor knowledge of services in the networks of attention to women victims of violence in the city, thus underscoring the fragility of these health institutions to prepare the reception and guidance of victims, mainly by not recognizing as an integral part of these networks. [19]

\section{Conclusions}

Based on the literature review, it is imminent that the region that most studies violence against women is located in São Paulo, and the Public Health magazines are the most interested in publications on the subject proposal. Most of the articles was published in 2011 and with Qualis of the $A_{2}$ magazines.

Some research showed limitations because these were research in documentary data, which were not filled in all the information needed for a more accurate research. Other research would gain greater relevance if the data variables of women who have suffered violence were presented in a separate table, since it would allow more detailed evaluation by other researchers/readers.

It is also noticed the importance of using the O93 code (classification of deaths by external causes such as deaths related to pregnancy/postpartum and indirect obstetric maternal deaths) to make an association of death from external causes and pregnancy, since there is little data and studies with this information, being relevant to develop new surveys throughout the country to enable investigating the magnitude of the occurrence of violence at this stage of a woman's life.

Regarding the perception of women victims of violence, the presence or not of the woman with the aggressor is encouraged by many factors, whether financial, emotional or family. Stressing that often the factor that makes them follow through with the complaint is actually no longer bear the humiliation of being beaten. Thus, women who suffer aggression should be motivated and supported by their families to express their wishes and needs, so that they can in time resume their well-being and their life projects.

Violence against women on the perspective of the professionals who offer them assistance present itself surrounded by theoretical knowledge about their assignments, as well as the knowledge of politics, but present several limitations to achieve the proposal for assistance to these women.

The need for training of professionals who are gateway to the care of women victims of violence is evident through the journals of our sample, particularly concerning the identification of cases, the appropriate host and links with other network services. Another observation scored in the research was the existence of some services and mainly features that enable the empowerment and protection of these victims.

Therefore, this study highlights the importance of understanding violence against women by various government bodies, as well as the need to highlight coping strategies of structural and behavioral constraints that still presents itself as a gap in assistance to the female audience.

\section{References}

1. Garcia LP, Freitas LRS, Höfelmann DA. Avaliação do impacto da Lei Maria da Penha sobre a mortalidade de mulheres por agressões no Brasil, 2001-2011. Epidemiologia dos Serviços de Saúde [Internet]. July 2013 [cited 2015 Jul7]; 22(3): 3839. Available from: http://scielo.iec.pa.gov.br/pdf/ess/v22n3/ v22n3a03.pdf 
2. Oshikata $C T$, Bedone $A J$, Papa $M S F$, Santos $G B$, Pinheiro $C D$, Kalles $\mathrm{AH}$. Características das mulheres violentadas sexualmente e da adesão ao seguimento ambulatorial: tendência observadas ao longo dos anos em um serviço de referência em Campinas, São Paulo, Brasil. Cad Saúde Pública [Internet]. 2011 [cited 2015 Jul 7]; 27 (4): 701-13. Available from: http://www.scielo.br/pdf/ csp/v27n4/09.pdf

3. Souza MT, Silva MD, Carvalho R. Revisão integrativa: o que é e como fazer. Einstein [Internet]. 2010 [cited 2015 Jul 12]; 8(1)1026. Available from: http://www.scielo.br/pdf/eins/v8n1/pt 16794508-eins-8-1-0102.pdf

4. Facurt CO, Fernandes AMS, Oliveira TS, Andrade TS, Azevedo RCS. Violência sexual: estudo descritivo sobre as vítimas e o atendimento em um serviço universitário de referência no Estado de São Paulo, Brasil. Cad Saúde Pública [Internet]. 2013 [cited 2015 Jul 5]; 29 (5): 889-98. Available from: http://ojs.c3sl. ufpr.br/ojs/index.php/cogitare/article/download/40355/25509.

5. Cordeiro LAMC, Cordeiro SM, Lima CC, Franco CLBF, Gradim CVC. Violência contra mulher: revisão integrativa. J NursUFPE on line [Internet]. 2013 [cited 2015 Jun 30]; 7(esp): 862-9. Available from: http://www.revista.ufpe.br/revistaenfermagem/ index.php/revista/article/download/3082/5737

6. Alves MMR, Alves SV, Antunes MBC, Santos DLP. Causas externas e mortalidade materna: proposta de classificação. Rev SaúdePúbl [Internet]. 2013 [cited 2015 Jun 30]; 47(2):28391. Available from: http://www.scielo.br/pdf/rsp/v47n2/00348910-rsp-47-02-0283.pdf

7. Lucena KDT, Silva ATMC, Moraes RM, Silva CC, Bezerra IMP. Análise espacial da violência doméstica contra a mulher entre os anos 2002 e 2005 em João Pessoa, Paraíba, Brasil. Cad Saúde Pública [Internet]. 2012 [cited 2015 Jul 7]; 28 (6): 1111-21. Available from: http://www.scielosp.org/pdf/csp/v28n6/10.pdf

8. Vieira EM. Perdona GSC, Santos MA. Fatores associados à violência física por parceiro íntimo em usuárias de serviços de saúde. Rev Saúde Públ [Internet]. 2011 [cited 2015 Jun 30]; 45(4):730-7. Available from: http://www.scielo.br/pdf/rsp/ v45n4/2647.pdf

9. Osis MJD, Duarte GA, Faúndes A. Violência entre usuárias de unidades de saúde: prevalência, perspectiva e conduta de gestores e profissionais. Rev Saúde Públ [Internet]. 2012 [cited 2015 Jul 4] ;46(2): 351-8. Available from: http://www.scielo.br/ $\mathrm{pdf} / \mathrm{rsp} / \mathrm{v} 46 \mathrm{n} 2 / 3137 . \mathrm{pdf}$

10. Meneghel SN, Hirakata VN, Feminicídios: homicídios femininos no Brasil. Rev SaúdePúbl [Internet]. 2011 [cited 2015 Aug 5]; 45(3):564-74. Available from: http://www.scielo.br/pdf/rsp/ v45n3/1931.pdf

11. Heise L, Kotsadam A. Cross-national and multilevel correlates of partner violence: an analysis of data from population-based surveys. Lancet Glob Health [Internet].2015 [cited 2015 Jun 18]; 3: 332-40. Available from: http://www.sciencedirect.com/ science/article/pii/S2214109X15000133

12. Vieira BL, PADOIN SMM, Souza IEO, Paula CC, Terra MG. Típico da ação das mulheres que denunciam o vivido da violência: contribuições para a enfermagem. Rev enferm UERJ [Internet]. 2011 [cited 2015 Aug 2]; 19(3):410-4. Available from: http:// www.facenf.ueri.br/v19n3/v19n3a12.pdf
13. Meneghel STN, Bairros F, Mueller B, Monteiro D, Oliveira LO, Collaziol ME. Rotas críticas de mulheres em situação de violência: depoimentos de mulheres e operadores em Porto Alegre, Rio Grande do Sul, Brasil. Cad Saúde Pública [Internet]. 2013 [cited 2015 Jul 10]; 27(4):743-52. Available from: http://www.scielo.br/ $\mathrm{pdf} / \mathrm{csp} / \mathrm{v} 27 \mathrm{n} 4 / 13 . \mathrm{pdf}$

14. Santos MA, Vieira EM. Recursos sociais para apoio às mulheres em situação de violência em Ribeirão Preto, SP, na perspectiva de informantes-chave. Interface [Internet]. 2011 [cited 2015 Aug 2]; 15 (36): 93 - 108. Available from: http://www.scielo.br/pdf/ icse/v15n36/a08v1536.pdf

15. Signorelli MC, Auad D, Pereira PPG. Violência doméstica contra mulheres e a atuação profissional na atenção primária à saúde: um estudo etnográfico em Matinhos, Paraná, Brasil. Cad Saúde Pública [Internet]. 2013 [cited 2015 Jul 10]; 29 (6): 1230-40. Available from: https://doaj.org/article/ cd5982c1cdec44b28540cc17e8a5e6f2

16. Kiss LB, Schraiber LB. Temas médico-sociais e a intervenção em saúde: a violência contra mulheres no discurso dos profissionais. Ciênc saúde coletiva [Internet]. [cited 2015 Jun 30]; 16(3):194352. Availablefrom: http://www.scielo.br/pdf/csc/v16n3/28.pdf

17. Gomes NP, Bonfim ANA, Diniz NMF, Souza SS, Couto TM. Percepção dos profissionais da rede de serviços sobre o enfrentamento da violência contra a mulher. Rev enferm UERJ [Internet].2012 [cited 2015 Jun 30] ;abr/jun; 20(2):1738. Available from: http://www.scielo.br/pdf/rgenf/v30n4/ a05v30n4.pdf

18. Hesler LZ, Costa MC, Resta DG, Colomé ICS. Violência contra as mulheres na perspectiva dos agentes comunitários de saúde. Rev GaúchaEnferm [Internet]. 2013 [cited 2015 Jul 27]; 34(1): 180-6. Available from: http://www.scielo.br/pdf/rgenf/v34n1/23.pdf

19. Santos SMP, Colaço EO, Silva FLS, Mesquita VGF, Gonçalves RL, Araújo CRF. Concepções e práticas de profissionais de saúde sobre a violência contra a mulher. J Nurs UFPE on line [Internet]. [cited 2015 Aug 5]; jan; 8(1):77-82. Available from: http://www. revista.ufpe.br/revistaenfermagem/index.php/revista/article/ download/5273/8317

\section{Publish in International Archives of Medicine}

International Archives of Medicine is an open access journal publishing articles encompassing all aspects of medical science and clinical practice. IAM is considered a megajournal with independent sections on all areas of medicine. IAM is a really international journal with authors and board members from all around the world. The journal is widely indexed and classified Q1 in category Medicine. 